Journal of Business \& Management (COES\&RJ-JBM)

ISSN (E): 2306-7179 ISSN (P): 2306-8043

Publisher: Centre of Excellence for Scientific \& Research Journalism, COES\&RJ LLC

Online Publication Date \& Issue: 1st April 2019, Vol.7, No.2, April 2019

https://doi.org/10.25255/jbm.2019.7.2.137.161

\title{
Modeling and Analysis of Bus Scheduling Systems of Public Bus Transport in Aqaba Special Economic Zone Authority
}

\begin{abstract}
Abdallah Abu Abdallah, MBA/Accounting Graduate at School of Management and Finance, The University of Jordan-Aqaba Branch, Jordan, abdallah.fareed@yahoo.com

Ra'ed Masa'deh, Department of Management Information Systems, School of Business, The University of Jordan, Amman, Jordan, r.masadeh@ju.edu.jo
\end{abstract}

\begin{abstract}
:
Aqaba Special Economic Zone Authority (ASEZA) City Bus Service is the only public enterprise that provides transport services in and around the city of Ababa. The city uses a fixed bus schedule system to serve passengers in 15 routes with buses (89) bus. However, this type of bus assignment system created a problem in the operational and financial performances. The objective of this paper is to develop an optimum bus assignment method using Linear Programming (LP). After thorough analysis of the existing bus scheduling system, the LP model is developed and used to determine the optimal number of buses for each route in four shifts. The output of the LP-model is then validated with the performances of the existing systems. The findings of the study show that There is a positive effect bus utilization on reduce cost in public transportation, there is a positive effect total number of trips made on reduce cost in public transportation, There is a positive effect total distance travelled on reduce cost in public transportation, There is a positive effect various operating costs on reduce cost in public transportation. The researcher recommended the (ASEZA) to adopt the new bus assignment system so that buses can be assigned based on the demand distribution of passengers for each route at a given shift.
\end{abstract}

\section{Keywords:}

Bus Scheduling Systems, Public Bus Transport, Aqaba, Jordan

\section{Citation:}

Abu Abdallah, Abdallah; Masa'deh, Ra'ed (2019). Modeling and Analysis of Bus Scheduling Systems of Public Bus Transport in Aqaba Special Economic Zone Authority; Journal of Business \& Management (COES\&RJ-JBM) Vol.7, No.2, pp.137-161, https://doi.org/10.25255/jbm.2019.7.2.137.161.

This work is licensed under a Creative Commons Attribution 4.0 International License. 


\section{Introduction}

AQABA city located in the far south of the Hashemite Kingdom of Jordan on the Red Sea Coast Latitude (31.95638607801807) and Longitude (35.94535052776337), the center of the area of Aqaba. It is about 330 kilometers south of the capital Amman. Its population in 2017 is about 198,500 people [1].

Buses service in AQABA city consist from individual operators and Aqaba Transport \& Logistics Company, the network of internal lines connecting the regions of the city with each other with (15) line, where works (89) big bus and medium bus to serve these lines as describe in table below.

\begin{tabular}{|c|c|c|c|c|c|}
\hline $\begin{array}{l}\text { Ownership of the } \\
\text { route }\end{array}$ & $\begin{array}{l}\text { Medium } \\
\text { bus - } \\
\text { individual } \\
\text { operators }\end{array}$ & $\begin{array}{c}\text { Large bus } \\
- \\
\text { individual } \\
\text { operators }\end{array}$ & $\begin{array}{l}\text { Medium } \\
\text { Bus - } \\
\text { Aqaba } \\
\text { Company }\end{array}$ & $\begin{array}{l}\text { Big Bus - } \\
\text { Aqaba } \\
\text { Company }\end{array}$ & route name \\
\hline Joint route & 2 & 0 & 2 & 0 & Bus station- Shalalah \\
\hline $\begin{array}{l}\text { Individual } \\
\text { operators }\end{array}$ & 1 & 0 & 0 & 0 & Country-port section 3 \\
\hline $\begin{array}{l}\text { Individual } \\
\text { operators }\end{array}$ & 1 & 0 & 0 & 0 & Country - AL-KHZAN \\
\hline $\begin{array}{c}\text { Aqaba Transport } \\
\text { \& Logistics } \\
\text { Company }\end{array}$ & 0 & 0 & 3 & 0 & Country - Al - Rimal - 10th \\
\hline $\begin{array}{c}\text { Aqaba Transport } \\
\text { \& Logistics } \\
\text { Company }\end{array}$ & 0 & 0 & 42 & 4 & Country - South Beach \\
\hline $\begin{array}{l}\text { Individual } \\
\text { operators }\end{array}$ & 2 & 0 & 0 & 0 & $\begin{array}{l}\text { Country - AL-ALAMEAH - AL- } \\
\text { MHDOUD }\end{array}$ \\
\hline Joint route & 3 & 0 & 3 & 0 & $\begin{array}{l}\text { Country - AL-SHABEAH - AL- } \\
\text { MHDOUD }\end{array}$ \\
\hline Joint route & 4 & 0 & 1 & 0 & Country - Area of AL-MHDOUD \\
\hline $\begin{array}{c}\text { Aqaba Transport } \\
\text { \& Logistics } \\
\text { Company }\end{array}$ & 0 & 0 & 2 & 0 & $\begin{array}{l}\text { Country-AL-MHDOUD } \\
\text { Western }\end{array}$ \\
\hline Joint route & 4 & 0 & 0 & 0 & Country - Factories Area \\
\hline $\begin{array}{c}\text { Aqaba Transport } \\
\text { \& Logistics } \\
\text { Company }\end{array}$ & 0 & 0 & 1 & 0 & Country - Saladin District \\
\hline $\begin{array}{c}\text { Aqaba Transport } \\
\text { \& Logistics } \\
\text { Company }\end{array}$ & 0 & 0 & 2 & 2 & $\begin{array}{l}\text { The ninth residential area - Al- } \\
\text { Harifa - Al Karama }\end{array}$ \\
\hline $\begin{array}{c}\text { Aqaba Transport } \\
\text { \& Logistics } \\
\text { Company }\end{array}$ & 0 & 0 & 3 & 0 & $\begin{array}{l}\text { Third - Residential Area VII - } \\
\text { VIII - VI }\end{array}$ \\
\hline $\begin{array}{c}\text { Aqaba Transport } \\
\text { \& Logistics } \\
\text { Company }\end{array}$ & 0 & 0 & 1 & 5 & $\begin{array}{l}\text { University of Jordan - } \\
\text { Industrial City - Airport }\end{array}$ \\
\hline
\end{tabular}


Modeling and Analysis of Bus Scheduling Systems...

\begin{tabular}{|c|c|c|c|c|c|}
\hline $\begin{array}{c}\text { Individual } \\
\text { operators }\end{array}$ & 0 & 1 & 0 & 0 & Port - residential units \\
\hline $\mathbf{8 9}$ & $\mathbf{1 7}$ & $\mathbf{1}$ & $\mathbf{6 0}$ & $\mathbf{1 1}$ & total \\
\hline
\end{tabular}

Bus scheduling is one of the operations planning process in bus Transport that deals about the good task of buses to serve the expected passenger demand, the planning process in public transportation consists of different regular and complex tasks which start at a strategic level.

At the operational level, collecting or forecasting the number of passengers at each transfer point is most of the time fully unknown, the decision-making process of bus mission is however, a trade-off between service quality and operating cost for the bus operating companies. It is because; using too many buses incurs more operating cost to the company whereas too few buses decrease the service quality level [2-7].

\begin{tabular}{|c|c|c|c|c|c|c|c|c|c|c|c|c|}
\hline $\begin{array}{l}\text { AVG- } \\
\text { Daily } \\
\text { Revenue }\end{array}$ & $\begin{array}{c}\text {-AVG } \\
\text { number of } \\
\text { trips }\end{array}$ & $\begin{array}{c}\text { Daily } \\
\text { Revenue }\end{array}$ & $\begin{array}{l}\text { NUMBER OF } \\
\text { PASSENGERS }\end{array}$ & $\begin{array}{c}\text { number of } \\
\text { trips }\end{array}$ & $\begin{array}{c}\text { Daily } \\
\text { Revenue }\end{array}$ & $\begin{array}{l}\text { NUMBER OF } \\
\text { PASSENGERS }\end{array}$ & $\begin{array}{c}\text { number } \\
\text { of trips }\end{array}$ & $\begin{array}{c}\text { Daily } \\
\text { Revenue }\end{array}$ & $\begin{array}{l}\text { NUMBER OF } \\
\text { PASSENGERS }\end{array}$ & $\begin{array}{l}\text { number } \\
\text { of trips }\end{array}$ & ROUT NAMR & $\#$ \\
\hline 103.18 & 22.33 & 60.06 & 273 & 13 & 106.26 & 483 & 23 & 143.22 & 651 & 31 & $\begin{array}{l}\text { Bus station- } \\
\text { Shalalah }\end{array}$ & 1 \\
\hline 107.8 & 23.33 & 78.54 & 357 & 17 & 92.4 & 420 & 20 & 152.46 & 693 & 33 & $\begin{array}{c}\text { Country-port } \\
\text { section } 3\end{array}$ & 2 \\
\hline 100.1 & 21.67 & 78.54 & 357 & 17 & 73.92 & 336 & 16 & 147.84 & 672 & 32 & $\begin{array}{c}\text { Country - AL- } \\
\text { KHZAN }\end{array}$ & 3 \\
\hline 63.14 & 13.67 & 32.34 & 147 & 7 & 50.82 & 231 & 11 & 106.26 & 483 & 23 & $\begin{array}{l}\text { Country-Al- } \\
\text { Rimal - 10th }\end{array}$ & 4 \\
\hline 107.8 & 23.33 & 78.54 & 357 & 17 & 110.88 & 504 & 24 & 133.98 & 609 & 29 & $\begin{array}{c}\text { Country- } \\
\text { South Beach }\end{array}$ & 5 \\
\hline 69.3 & 15.00 & 64.68 & 294 & 14 & 55.44 & 252 & 12 & 87.78 & 399 & 19 & $\begin{array}{l}\text { Country - AL- } \\
\text { ALAMEAH - } \\
\text { AL-MHDOUD }\end{array}$ & 6 \\
\hline 23.1 & 5.00 & 18.48 & 84 & 4 & 32.34 & 147 & 7 & 18.48 & 84 & 4 & $\begin{array}{c}\text { Country - AL- } \\
\text { SHABEAH - AL- } \\
\text { MHDOUD }\end{array}$ & 7 \\
\hline 35.42 & 7.67 & 41.58 & 189 & 9 & 27.72 & 126 & 6 & 36.96 & 168 & 8 & $\begin{array}{c}\text { Country-Area } \\
\text { of AL- } \\
\text { MHDOUD }\end{array}$ & 8 \\
\hline \multirow[t]{2}{*}{84.7} & 18.33 & 83.16 & 990 & 18 & 87.78 & 1045 & 19 & 83.16 & 990 & 18 & $\begin{array}{l}\text { Country-AL- } \\
\text { MHDOUD } \\
\text { Western }\end{array}$ & 9 \\
\hline & & & 3048 & & & 3544 & & & 4749 & & & \\
\hline
\end{tabular}

The decision-making process of bus assignment is however, a trade-off between service quality and operating cost for the bus operating companies. It is because; using too many buses incurs more operating cost to the company whereas too few buses decrease the service quality level.

The current network of lines within the city of Aqaba consists of (89) public vehicles distributed over (15) lines, the number of passengers shows high variability during each periods of time that requires fluctuation of number of assigned buses in each route, uses a fixed number of buses scheduled per route in its operation throughout the day. This resulted in the fact that, some buses move empty while others are overcrowded, which subsequently result in poor performance on bus utilization, distance travelled, number of trips and service quality [8]. 
Journal of Business \& Management (COES\&RJ-JBM), 7(2), pp. 137-161
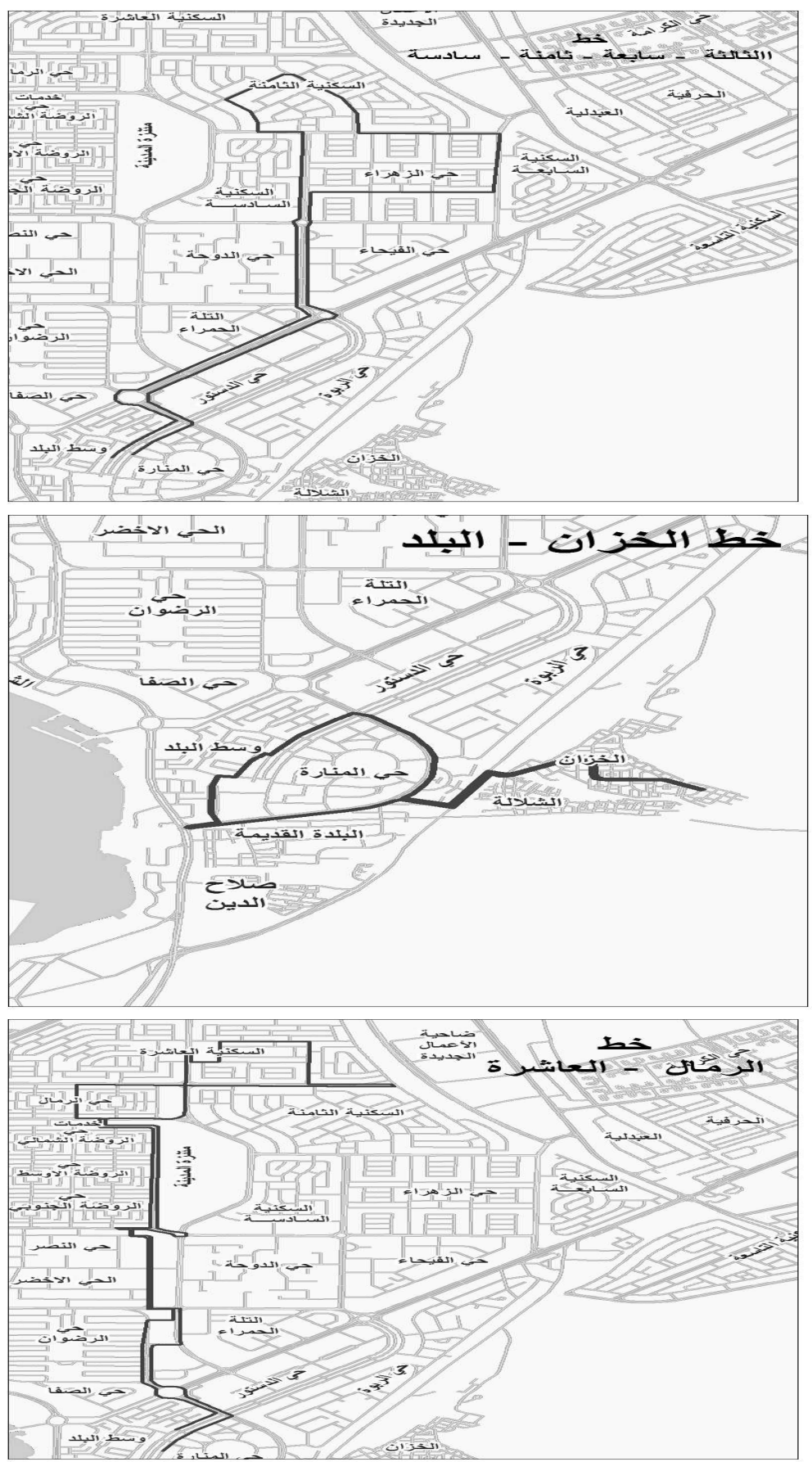
Modeling and Analysis of Bus Scheduling Systems...
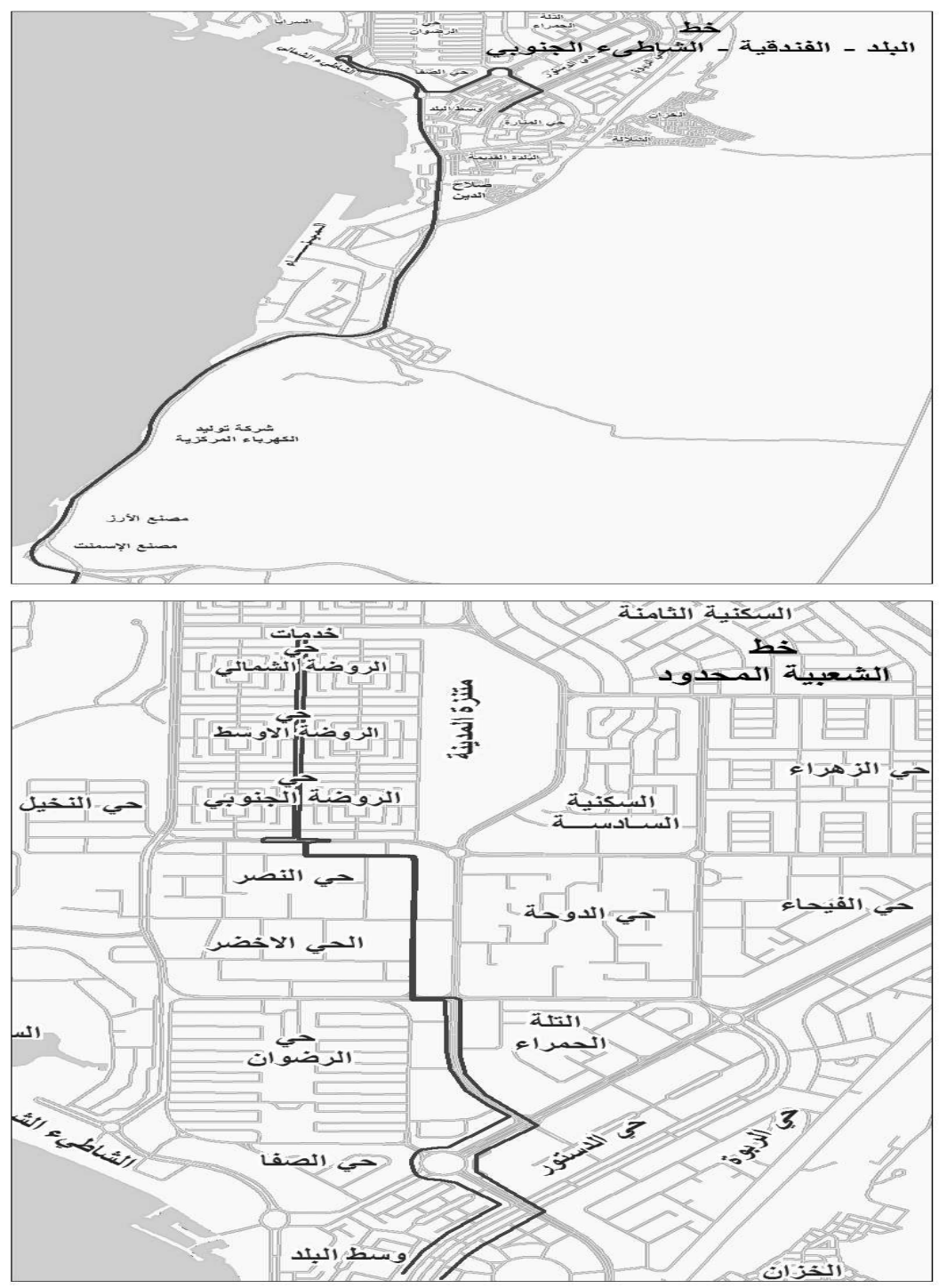
Journal of Business \& Management (COES\&RJ-JBM), 7(2), pp. 137-161
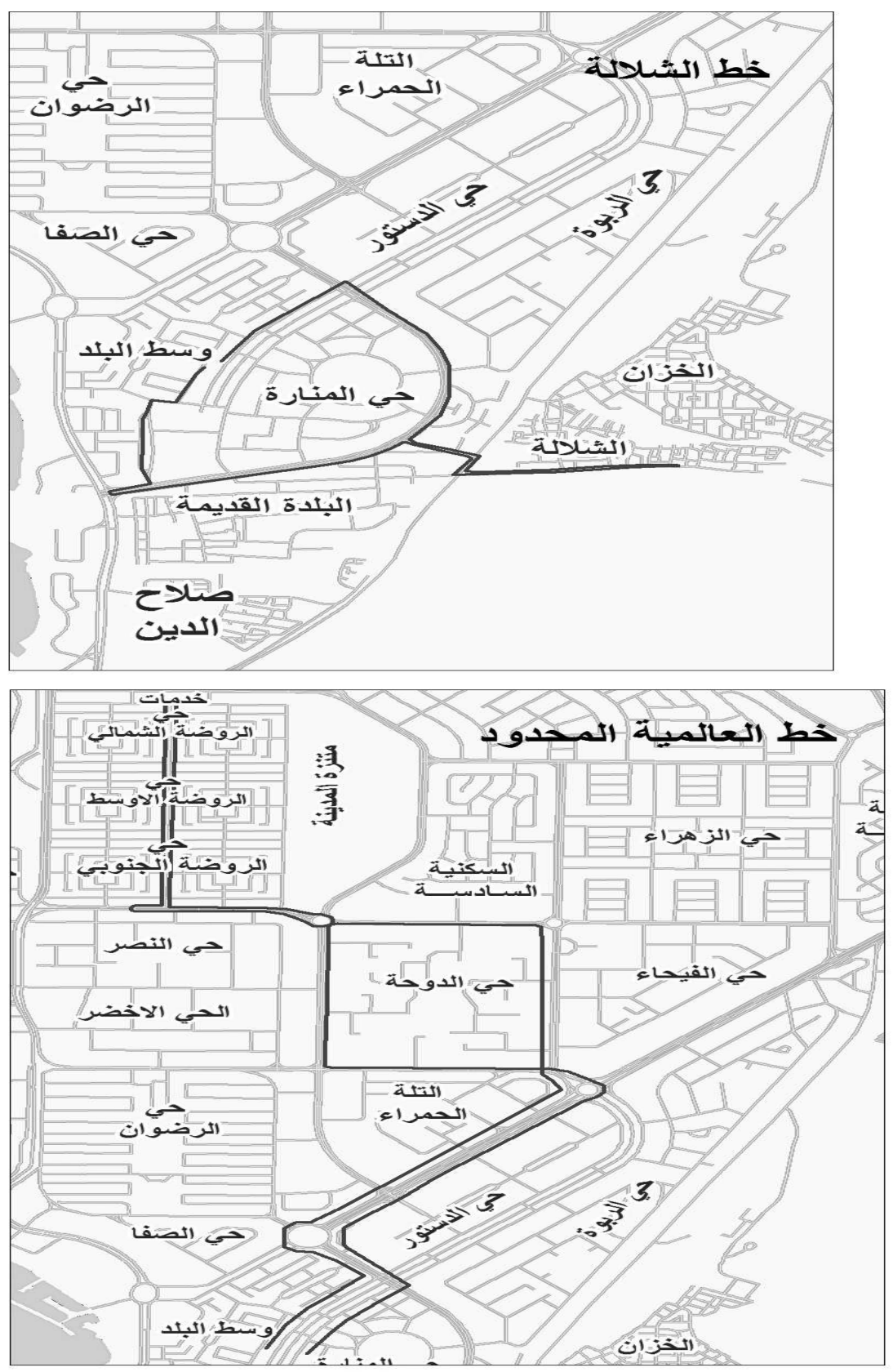
Modeling and Analysis of Bus Scheduling Systems...
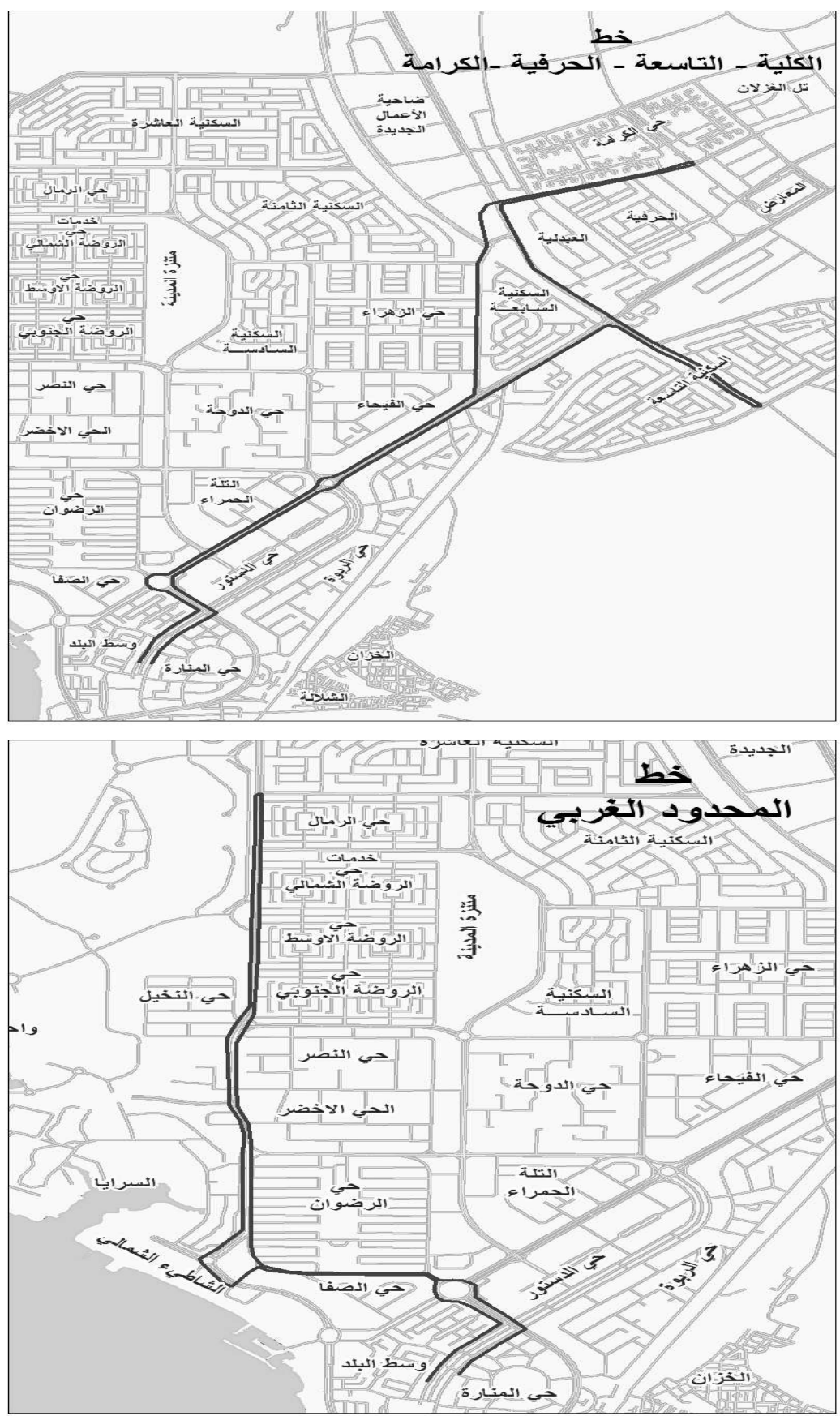
Journal of Business \& Management (COES\&RJ-JBM), 7(2), pp. 137-161
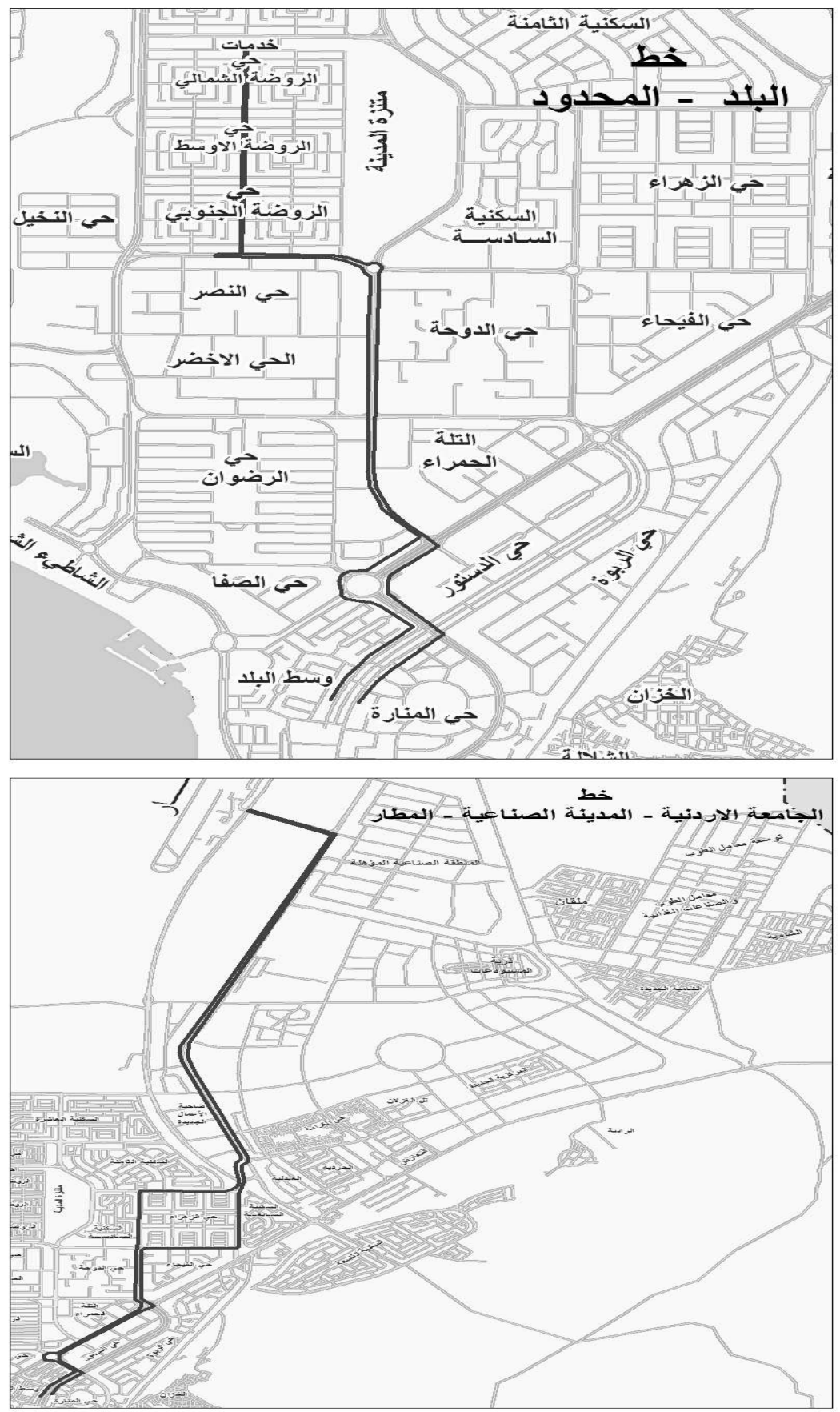
Modeling and Analysis of Bus Scheduling Systems...

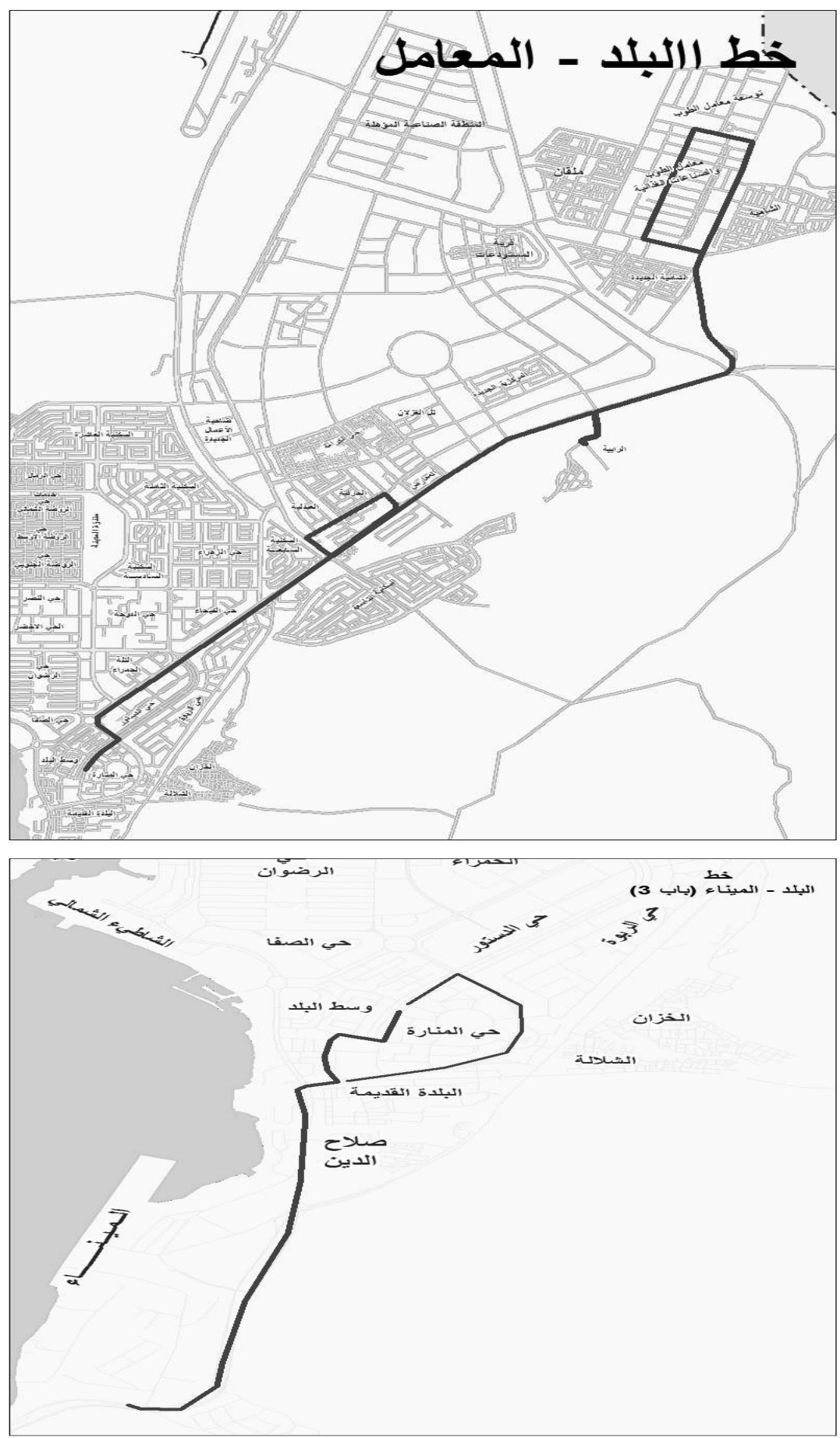




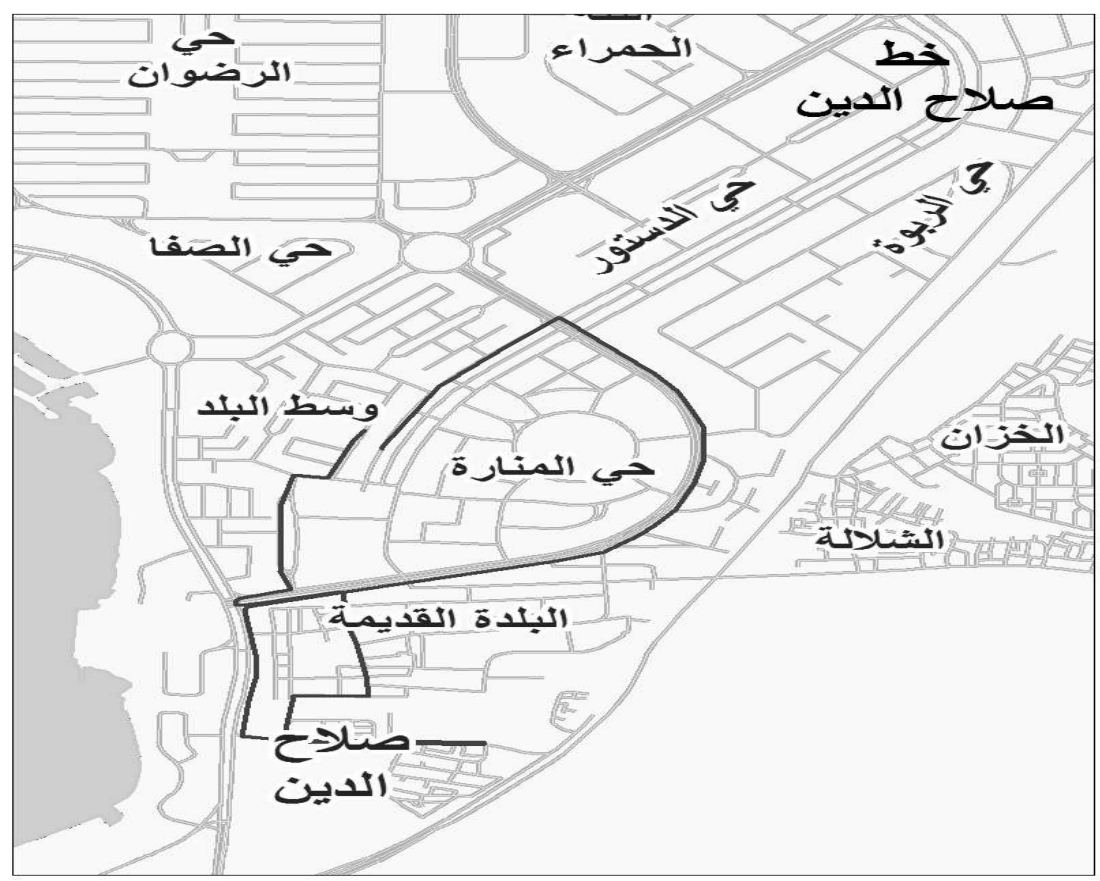

In this paper, the bus assignment and scheduling problems faced in AQABA City is modeled and analyzed using Linear Programming (LP) model, It is used to determine optimum bus assignment that can improve the existing bus schedule and assignment systems, Thus, this paper first focuses on developing a demand oriented LP-model for the bus assignment problems of AQABA City in four operating time periods in a day based on the 15 selected routes, For simplicity the four operating time periods named as shift for the purpose of this research .

\section{Literature Review}

The task of designing delivery or unplanned routes to service customers in the transport and supply chain is known in the literature as a Vehicle Routing Problem (VRP), Dantzig and Ramser [9] proposed VRP for the first time under the title "Truck dispatching problem" with the objective of designing optimum routing of a fleet of gasoline delivery trucks between a bulk terminal and many service stations.

VRP is a generic name given to a whole class of problems in which a set of routes for a fleet of vehicles based at one or several depots must be determined for many geographically dispersed cities or customers $[10,11,12]$. It is defined by a depot, a set of geographically dispersed customers with known demands, and a set of vehicles with fixed capacity (In general, the objective of VRP is to minimize the overall distribution costs.) $[9,11]$.

The general or classical VRP consists of designing a set of at most $\mathrm{K}$ delivery or collection routes such that: each route starts and ends at the workshop, each customer is visited exactly once by exactly one vehicle, the total demand of each route does not exceed the vehicle capacity and the total routing cost is minimized. 
Vehicle Scheduling Problem (VSP) is one of the branches of Vehicle Routing Problems (VRP) and its main function is to schedule vehicles to trips according to passenger demand and resource availability, The VRP can be represented in graph theory.

Let $G=(V, A)$ be a complete graph where, $V=\{0,1 \ldots n\}$ is a vertex set and $A$ is an arc set. Vertices $j=(1 \ldots n)$ correspond to the customers, each with a known non-negative demand, ( $\mathrm{Dj})$, whereas vertex 0 corresponds to the depot. $A$ non- negative cost, $(C \mathrm{ij})$, is associated with each $\operatorname{arc}(i, j) \varepsilon A$ and represents the cost, distance or time of traveling from vertex (i) to vertex $\mathrm{j}$. [15,16].

The most common objective of VSP is mainly to minimize the number of vehicles required and to reduce the day-to-day operating cost $[17,18]$, there are different approaches and models used for vehicle scheduling problems. Among the many others, Xue, eta, developed a model for Ambiguous Optimization of Vehicle Scheduling in Open Coal Mine with the objective to use the minimum number of truck under the condition of fulfilling the task or to find the minimum expected number of trucks to be used $A$ mathematical model for the bus scheduling problem to determinate the bus departure rate as a function of time was also introduced by Salzborn.

The other transportation scheduling problems such as driver scheduling, bus controlling strategy and air craft scheduling are also approached by different authors with similar VRP concept [19, 20, 21]. For example, genetic algorithm techniques for driverscheduling problem [2223], lagrangean relaxation of a linear integer-programming problem with a sub-gradient optimization and tree search procedure for crew scheduling problem [24, 25, 26], a stochastic-demand scheduling model for aircraft scheduling [27]. The bus controlling strategy is thus a very important issue to improve the reliability of bus service and widely addressed by many authors [28-33]. Most of the VRPs are very complex, general and Non-Polynomial-Hard (NP-hard) by their nature, which could not be implemented easily. However, the model developed in this paper is new by its nature, introduce some new parametric value and can easily be with implemented with little modification by any public transport system.

\section{Theoretical Framework and Hypotheses Development}

This research is based on the proposed LP-Model, The LP-Model considers the effect of bus utilization, total number of trips made, total distance travelled, various operating costs on reduce cost in public transportation, LP-Model was developed to obtain a solution for the bus assignment problems of the AQABA City.

\section{Research Hypotheses}

- H1: There is a positive effect of bus utilization on reduce cost in public transportation.

- $\quad \mathrm{H} 2$ : There is a positive effect of total number of trips made on reduce cost in public transportation.

- H3: There is a positive effect of total distance travelled on reduce cost in public transportation.

- H4: There is a positive effect of various operating costs on reduce cost in public transportation. 


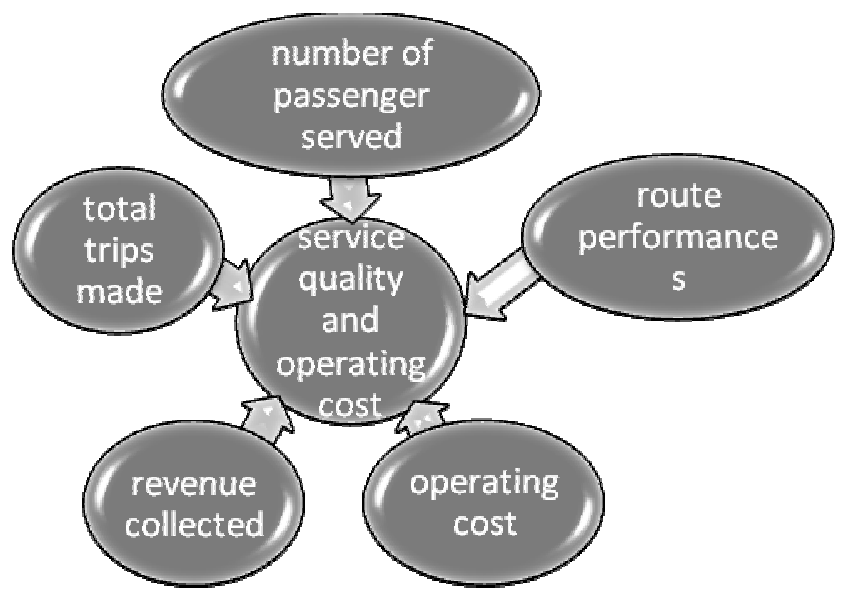

\section{Research Methodology}

The methodology used in this research has followed the following basic four steps, these are

1 .

2 .

3.

4

\section{Data Collection}

To achieve the study goals that aim to reduce cost in public transportation, Though the AQABA City is operating on 15 routes, the data collection focuses on these routes, which have been used in the bus operations for more than a period, the data collected includes:

1.

2.

3.

4.

5.

The data regarding the available facility of the data regarding the available facility of Aqaba Special Economic Zone Authority; such as

1.

2.

3.

4.

5. Route performances.

Number of passenger served.

Total trips made.

Revenue collected.

Operating cost and total distance covered

The number of buses both operational and non-operational.

Their capacity.

Bus travel time.

Route length.

Working hours were also collected from the current timetable.

The data were analyzed and organized per shift per route basis for validation purpose. In this paper shift means the working time based on demand distribution. 
Modeling and Analysis of Bus Scheduling Systems...

\begin{tabular}{|l|c|c|c|c|}
\hline \multirow{2}{*}{ Shift } & \multicolumn{2}{|c|}{ Time Interval } & \multirow{2}{*}{$\begin{array}{c}\text { Duration } \\
\text { (Min.) }\end{array}$} & $\begin{array}{c}\text { WJ-number of trips } \\
\text { Total Duration /30MIN }\end{array}$ \\
\cline { 2 - 3 } & from & to & & 2.6 \\
\hline Morning Peak & 7 & 8.3 & 78 & 13.4 \\
\hline First off-peak & 8.3 & 15 & 402 & 8.6 \\
\hline Evening peak & 15 & 19.3 & 258 & 3.4 \\
\hline Second off-peak & 19.3 & 21 & 102 & $\mathbf{2 8}$ \\
\hline TOTAL & & & $\mathbf{8 4 0}$ & \\
\hline
\end{tabular}

As shown in Table above (Demand proportion and duration of each shift)

AQABA buses dispatched an average fleet of 89 buses and transported about 3157 passengers per day in 15 routes in addition to these, average a city bus covers about $15.70-\mathrm{km}$ per day and makes 22 trips per day. The AQABA buses have two types of schedules for its operation in four shift, i.e. peak hour and off-peak hour schedules. These are two peaks and two off-peak shifts during its operation hours (from 6:30am to 21:0pm). The two peaks are: the morning peak from (7.00 am -8:30am) and after-noon peak from (15:15 pm-19:30pm). The reaming hours are the off-peak in the morning and the after-noon shift. The period, the time interval, the duration and the demand proportion of each time or shift is shown in Table- Demand proportion and duration of each shift.

\section{Model Development}

The current schedule of AQABA buses shows the total distance coverage is about 300 kilometers and 197 trips per day for the 9 routes and passengers (9498) per day. Increasing kilometer covered means increasing service availability if the assignment of buses is based on the demand distribution of a given route but incurs unnecessary cost if the assignment is not demand oriented. Due to this reason a very close look is required to design and analyze a model that can assign buses optimally and assess the bus utilization of the enterprise. After analyzing the existing bus scheduling systems of AQABA buses, an LP-Model was developed to obtain a solution for the bus assignment problems of the enterprise, The LP model developed in this study is easier either for computation or to apply for real problems of bus scheduling. It is a new approach in the literatures of VRP since it addresses a mixed heterogeneous fleet in 9 routes and four shifts with many constraints. Moreover, unlike other variants of VRP, it introduces additional parameters like trip factor and demand proportion. It also directly used to find optimum numbers of trips made each bus type. The model is used to solve problem in public bust transport, based on the demand distribution of passengers in 9 routes and four operating shifts. But unlike Mehmet, et al [34], it addresses the trips made by heterogeneous fleets directly in the model with more number of constraints in it.

1- Running the Model

Using the data collected, the LP model was fitted to its input parameters. The model developed was coded and solved.

The resulting solution of the LP-model was:

a. The number of trips per route per shift for each type of bus. After obtaining the solution.

b. The number of trips was converted into number of buses per route per shift for each type of bus. 


\section{2- Model Validation}

The LP model was analyzed to identify potential areas of improvement in the bus scheduling and assignment problem of AQABA buses. It is also used to assign buses to a given route at a given shift based on the demand distribution of passengers in the four operating shifts in 9 routes. The findings of the LP-model were validated by comparing its performances with the performances of the existing bus scheduling systems of AQABA buses.

The validation was made on four performance measuring parameters namely

1. Bus utilization.

2. Total number of trips made.

3. Total distance travelled.

4. Various operating costs.

\section{LP-Model Development}

The LP-model deals with the assignment of optimum number of buses for each shift with the available fleet size and different constraints in such a way that bus utilization is improved, and operating costs are reduced with better service level. The model determines the total number of buses required with the objective of optimizing the number of buses required so that the operation cost would be minimized indirectly.

The 22-seat capacity bus with total capacity of 44 passengers is labeled as bus type- 1 and the 50-seat capacity with total capacity of 100 passengers as bus type-II. Each of them has a fleet size of 78 and 11 respectively. The total bus capacity is computed as the sum of the seat and standing capacity. For this paper, it is determined based on international standards [31]. Thus, the objective function of the LP model is to determine the optimum number and mix of these two types of buses.

Let xij and yij is number of trips made by bus type-I and bus type-I, then the LP model that determines the optimum number of trips required per route per shift is formulated as: Though the enterprise is operating on 15 routes, the data collection focuses only on the first 9 routes, which have been used in the bus operations for more than a decade.

$$
\begin{aligned}
& \text { Minimize: } \sum_{i=1}^{9} \sum_{j=1}^{4}\left(x_{i j}+y_{i j}\right) \\
& \text { Subject to } \\
& 44 x_{i j}+100 y_{i j} \geq D_{i j} \\
& { }^{9} \quad \sum_{j=1}^{4} x \leq 78^{*} \sum{ }^{9} \sum^{4} T \\
& \sum_{i=1} \sum_{j=1}^{4} i j \sum_{i=1} \sum_{j=1} i j \\
& \sum_{i=1}^{9} \sum_{j=1}^{4} y \leq 11 * \sum_{i=1}^{9} \sum_{j=1}^{4} T \\
& 9 \begin{array}{lll}
4 & 4 & 4 \\
\sum & (x i j+y i j) \leq 9 * & \sum w j
\end{array} \\
& \sum_{i=1} \sum_{j=1}\left(x_{i j}+y_{i j}\right) \leq 9^{*} \quad \sum_{j=1} w_{j} \\
& { }_{i j} \leq 78^{*} P T_{i} i j \\
& y \leq 11 * P T \\
& \text { ij } \quad i \quad i j \\
& \sum P \quad=1 \\
& { }_{i=1} i \\
& x_{i j}, i j \geq 0
\end{aligned}
$$


$\forall_{i}, i=1,2, \ldots 9, \forall_{j},=1,2,3,4$

Where: $\mathrm{i}=$ Route index, $\mathrm{j}=$ shift index, $\mathrm{Dij}=$ Passenger demand of route $\mathrm{i}$ at shift $\mathrm{j}, \mathrm{Pi}=$ trip proportion for route $\mathrm{i}, \mathrm{wj}=$ Minimum number of trips required at a given shift $\mathrm{j}, \mathrm{Tij}=$ Trip factor, maximum trips a bus can made on route $i$ at a given shift

- Equation 2 ensures the total trips made by the two types of buses must satisfy or exceeds the demand of route $i$ during shift $j$. Equation 3 and 4 also ensure the total numbers of trips to be made is less than or equal to the total available trips made by bus type-I and bus type-II respectively.

- Equation 5 entails the number of made by either type of buses be at least equals to the minimum number of trips required for a given route i during that shift j. Equation 6 and 7 are the number of trips assigned to route $i$ on shift $j$ less or equals to the number of trips available for route $i$ and shift $\mathrm{j}$ for bus type-I and type-II respectively.

-Equation 8 ensures the sum of all the trip proportion must be unity and finally Equation 9 indicates the non-negativity restriction. The model introduces a new approach by including different bus types in a simple LP model. It also assumes 30 minutes for one round trip for each route as a cycle time for all the shifts.

This is used to determine the total number of trips required by each type of bus for route $\mathrm{i}$ during shift $\mathrm{j}$. The actual number of buses to be used for the corresponding routes and shifts can be obtained from the total trips.

The travel time of bus on a given route is the total sum of passenger staying and stopping time (dwell time), tea and lunch break, rushing and deceleration at bus stops, traffic light and transfer time between each stop, However, few considerations were also considered both in terms of the functionality of the model itself and its output.

However, few considerations were also taken into account both in terms of the functionality of the model itself and its output. In particular, the model was run once for all of the four shifts. Although there were different bus sizes considerations in AQABA buses, constraint 2 includes bus size 44 and 100, which is are taken from the international urban bus standards. The number of buses will be checked to make sure wj is met for all time slots. The results obtained may be fractional but rounded later into upper integer values.

From the model, some of the parameters need to be defined for clarity. Owing to this, the minimum number of trips required at shift $j$ to meet the maximum allowable cycle time of 30 minutes. It depends on the duration of the time period and maximum allowable waiting time at a given shift.

The value of wj which is the minimum number of trips required at shift $j$ to meet the maximum allowable waiting time depends on the duration of the time and maximum allowable waiting time. For example, if a single trip time for a given shift is 30 minutes and the length of the period is 4hours for a given shift, then a minimum of 8 trips are required to limit the maximum waiting time of passenger to 30 minutes. This means, there should be at least one bus in every 30 minutes or half an hour for each shift for the quality of the service. wj is computed as follow: 
Journal of Business \& Management (COES\&RJ-JBM), 7(2), pp. 137-161

\begin{tabular}{|l|c|c|c|c|c|}
\hline \multirow{2}{*}{$\begin{array}{c}\text { Shift - OLD } \\
\text { SYSTEM }\end{array}$} & \multicolumn{2}{|c|}{ Time Interval } & Durati & WJ \\
& from & to & $\begin{array}{c}\text { on } \\
\text { (Min.) }\end{array}$ & $\begin{array}{c}\text { Total Duration /30MIN= } \\
\text { number of trips }\end{array}$ \\
\hline Morning Peak & 7 & 8.3 & 78 & 2.6 \\
\hline First off-peak & 8.3 & 15 & 402 & 13.4 \\
\hline Evening peak & 15 & 19. & 258 & 8.6 \\
\hline $\begin{array}{l}\text { Second off- } \\
\text { peak }\end{array}$ & 19.3 & 21 & 102 & 3.4 \\
\hline TOTAL & & & & $\mathbf{8 4 0}$ \\
\hline
\end{tabular}

30 Minutes

Morning Peak $=78$

$2.6=$

30 Minutes

This means, there should be at least (2.6) bus in every 30 minutes for each shift for the quality of the service.

The other parameter that needs to be determined is the trip factor, Tij. This is the number of trips a bus can make on route $i$ at a given shift $j$. Since the model computes the total trips that are required per route per shift, the trip factor is used to compute the available number of trips per route per shift. It is given by:

Total Duration for Shift $j$ (Minutes)

$t i_{j}=$

Single trip travel time for route $i$
Total Duration for Shift $j(78)$
30


Modeling and Analysis of Bus Scheduling Systems...

\begin{tabular}{|c|c|c|c|c|c|c|c|c|c|c|c|c|}
\hline $\begin{array}{l}\text { AVG- } \\
\text { Daily } \\
\text { Revenue }\end{array}$ & $\begin{array}{c}\text {-AVG } \\
\text { number of } \\
\text { trips }\end{array}$ & $\begin{array}{c}\text { Daily } \\
\text { Revenue }\end{array}$ & $\begin{array}{l}\text { NUMBER OF } \\
\text { PASSENGERS }\end{array}$ & $\begin{array}{c}\text { number of } \\
\text { trips }\end{array}$ & $\begin{array}{c}\text { Daily } \\
\text { Revenue }\end{array}$ & $\begin{array}{l}\text { NUMBER OF } \\
\text { PASSENGERS }\end{array}$ & $\begin{array}{l}\text { number } \\
\text { of trips }\end{array}$ & $\begin{array}{c}\text { Daily } \\
\text { Revenue }\end{array}$ & $\begin{array}{l}\text { NUMBER OF } \\
\text { PASSENGERS }\end{array}$ & $\begin{array}{l}\text { number } \\
\text { of trips }\end{array}$ & ROUT NAMR & \# \\
\hline 103.18 & 22.33 & 60.06 & 273 & 13 & 106.26 & 483 & 23 & 143.22 & 651 & 31 & $\begin{array}{l}\text { Bus station- } \\
\text { Shalalah }\end{array}$ & 1 \\
\hline 107.8 & 23.33 & 78.54 & 357 & 17 & 92.4 & 420 & 20 & 152.46 & 693 & 33 & $\begin{array}{l}\text { Country-port } \\
\text { section } 3\end{array}$ & 2 \\
\hline 100.1 & 21.67 & 78.54 & 357 & 17 & 73.92 & 336 & 16 & 147.84 & 672 & 32 & $\begin{array}{l}\text { Country - AL- } \\
\text { KHZAN }\end{array}$ & 3 \\
\hline 63.14 & 13.67 & 32.34 & 147 & 7 & 50.82 & 231 & 11 & 106.26 & 483 & 23 & $\begin{array}{l}\text { Country - Al - } \\
\text { Rimal - 10th }\end{array}$ & 4 \\
\hline 107.8 & 23.33 & 78.54 & 357 & 17 & 110.88 & 504 & 24 & 133.98 & 609 & 29 & $\begin{array}{l}\text { Country - South } \\
\text { Beach }\end{array}$ & 5 \\
\hline 69.3 & 15.00 & 64.68 & 294 & 14 & 55.44 & 252 & 12 & 87.78 & 399 & 19 & $\begin{array}{c}\text { Country - AL- } \\
\text { ALAMEAH - AL- } \\
\text { MHDOUD }\end{array}$ & 6 \\
\hline 23.1 & 5.00 & 18.48 & 84 & 4 & 32.34 & 147 & 7 & 18.48 & 84 & 4 & $\begin{array}{c}\text { Country - AL- } \\
\text { SHABEAH - AL- } \\
\text { MHDOUD }\end{array}$ & 7 \\
\hline 35.42 & 7.67 & 41.58 & 189 & 9 & 27.72 & 126 & 6 & 36.96 & 168 & 8 & $\begin{array}{l}\text { Country-Area of } \\
\text { AL-MHDOUD }\end{array}$ & 8 \\
\hline 84.7 & 18.33 & 83.16 & 990 & 18 & 87.78 & 1045 & 19 & 83.16 & 990 & 18 & $\begin{array}{l}\text { Country -AL- } \\
\text { MHDOUD } \\
\text { Western }\end{array}$ & 9 \\
\hline & & & 3048 & & & 3544 & & & 4749 & & & \\
\hline
\end{tabular}

\section{B- $\quad$ Model Output}

The LP model developed is solved based on the average daily demand for the last period in four operating shift time. The daily passengers' demand for the last period was collected and then the average daily passenger' demand of each month was computed per route per shift based on the trip proportion $\left(P_{i}\right)$ of route $i$.

\section{C- $\quad$ Assigning Buses to Routes}

From the output of LP-model there are about 451 total trips required to serve the average daily demand. The actual number of buses required for a given route $i$ during a given shift $j$ depends on the trip factor. That is the number of trips that can be made by each bus type during a given shift. Thus, the output needs to be transformed to number of buses required for each route per shift based on the possible trips that a bus can make during a given shift $j$ on each route $i$. From the output of the LP model shown, the number of trips can be transformed into number buses using the following equation.

\section{Number of Trips}

Number of Bus () 国

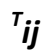

\section{2 ?}

$\begin{array}{ll} & 31 \\ 2.6\end{array}$

$T_{i j}$. This is the number of trips= number of buses bus can make on route $i$ at a given shift $j$

- in this case just (Accidentally) 
Journal of Business \& Management (COES\&RJ-JBM), 7(2), pp. 137-161

\begin{tabular}{|l|c|c|c|c|c|c|c|c|c|}
\hline \multicolumn{1}{|c|}{ ROUT NAMR } & $\begin{array}{c}\text { number of } \\
\text { trips }\end{array}$ & $\begin{array}{c}\text { Number of } \\
\text { Bus - } \\
\text { Morning } \\
\text { Peak } \\
\text { (NEW } \\
\text { SYSTEM) }\end{array}$ & $\begin{array}{c}\text { Number } \\
\text { of Bus - } \\
\text { First off- } \\
\text { peak } \\
\text { (NEW } \\
\text { SYSTEM) }\end{array}$ & $\begin{array}{c}\text { Number of } \\
\text { Bus - } \\
\text { Evening } \\
\text { peak } \\
\text { (NEW } \\
\text { SYSTEM) }\end{array}$ & $\begin{array}{c}\text { Number } \\
\text { of Bus - } \\
\text { Second } \\
\text { off-peak } \\
\text { (NEW } \\
\text { SYSTEM) }\end{array}$ & $\begin{array}{c}\text { Number } \\
\text { of Bus - } \\
\text { Morning } \\
\text { Peak } \\
\text { (OLD } \\
\text { SYSTEM) }\end{array}$ & $\begin{array}{c}\text { Number } \\
\text { of Bus - } \\
\text { First off- } \\
\text { peak } \\
\text { (OLD } \\
\text { SYSTEM) }\end{array}$ & $\begin{array}{c}\text { Number } \\
\text { of Bus - } \\
\text { Evening } \\
\text { peak } \\
\text { (OLD } \\
\text { SYSTEM) }\end{array}$ & $\begin{array}{c}\text { Number } \\
\text { of Bus - } \\
\text { Second } \\
\text { off-peak } \\
\text { (OLD } \\
\text { SYSTEM) }\end{array}$ \\
\hline Bus station- Shalalah & 31 & 12.0 & 2.0 & 4.0 & 9.0 & 4.0 & 4.0 & 4.0 & 4.0 \\
\hline Country-port section 3 & 33 & 13.0 & 3.0 & 4.0 & 10.0 & 1.0 & 1.0 & 1.0 & 1.0 \\
\hline Country - AL-KHZAN & 32 & 12.0 & 2.0 & 4.0 & 9.0 & 1.0 & 1.0 & 1.0 & 1.0 \\
\hline $\begin{array}{l}\text { Country - Al - Rimal - } \\
\text { 10th }\end{array}$ & 23 & 1.0 & 2.0 & 3.0 & 7.0 & 3.0 & 3.0 & 3.0 & 3.0 \\
\hline Country - South Beach & 29 & 11.0 & 2.0 & 3.0 & 9.0 & 46.0 & 46.0 & 46.0 & 46.0 \\
\hline $\begin{array}{l}\text { Country - AL- } \\
\text { ALAMEAH - AL- } \\
\text { MHDOUD }\end{array}$ & 19 & 7.0 & 1.0 & 2.0 & 6.0 & 6.0 & 6.0 & 6.0 & 6.0 \\
\hline $\begin{array}{l}\text { Country - AL- } \\
\text { SHABEAH - AL- }\end{array}$ & 4 & 2.0 & 0.0 & 1.0 & 1.0 & 2.0 & 2.0 & 2.0 & 2.0 \\
\hline $\begin{array}{l}\text { MHDOUD } \\
\text { MHDintry - Area of AL- }\end{array}$ & 8 & 3.0 & 1.0 & 1.0 & 2.0 & 5.0 & 5.0 & 5.0 & 2.0 \\
\hline $\begin{array}{l}\text { Country -AL-MHDOUD } \\
\text { Western }\end{array}$ & 18 & 7.0 & 1.0 & 2.0 & 5.0 & 2.0 & 2.0 & 2.0 & 2.0 \\
\hline
\end{tabular}

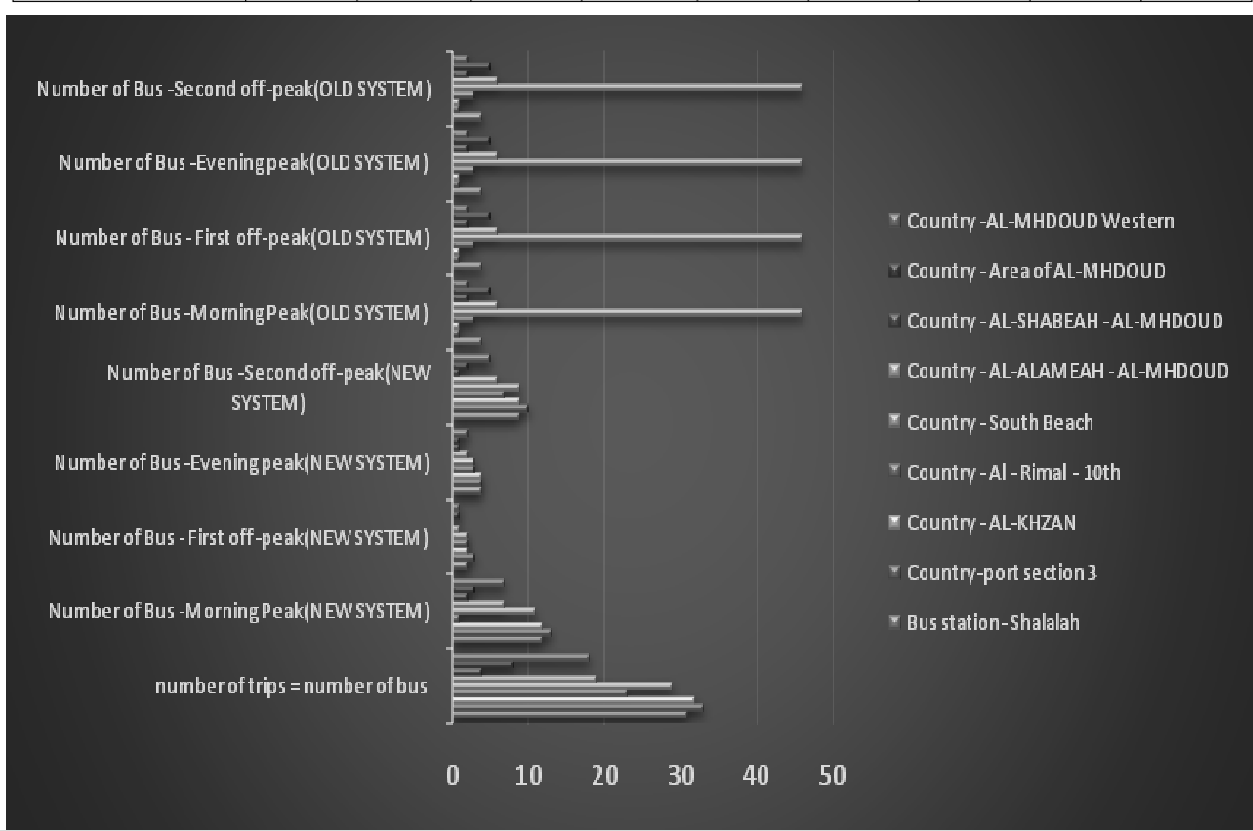

\section{Model Validations}

The output of the model is then evaluated using various performance measuring parameters. For the validation purpose, different comparisons were mad between the existing and the LP improved systems. The comparisons made were based on: -

A- Bus utilizations.

B- Distance.

C- Trips covered.

D- The different operating costs of the enterprise and each of them are discussed in the following sections.

\section{A- Bus Utilizations}

After assigning buses to each route and each shift, then the improvement achieved by the LP model were compared with the existing bus utilization of AQABA buses. Bus 
utilization is computed as the ratio of the number of passengers getting on the bus to the passengers carrying capacity. The average daily bus utilization of the existing and the improved systems are shown in Figure1. The findings show that the improved system has better bus utilization than the existing one.

\begin{tabular}{|c|l|c|c|}
\hline$\#$ & \multicolumn{1}{|c|}{ ROUT NAMR } & $\begin{array}{c}\text { number of trips = number } \\
\text { of bus - old system }\end{array}$ & $\begin{array}{c}\text { number of trips = } \\
\text { number of bus - } \\
\text { new system }\end{array}$ \\
\hline 1 & Bus station- Shalalah & 31 & 27 \\
\hline 2 & Country-port section 3 & 33 & 30 \\
\hline 3 & Country - AL-KHZAN & 32 & 27 \\
\hline 4 & Country - Al - Rimal - 10th & 23 & 13 \\
\hline 5 & Country - South Beach & 29 & 25 \\
\hline 6 & $\begin{array}{l}\text { Country - AL-ALAMEAH - AL- } \\
\text { MHDOUD }\end{array}$ & 19 & 16 \\
\hline 7 & $\begin{array}{l}\text { Country - AL-SHABEAH - AL- } \\
\text { MHDOUD }\end{array}$ & 4 & 4 \\
\hline 8 & Country - Area of AL-MHDOUD & 8 & 7 \\
\hline 9 & Country -AL-MHDOUD Western & 18 & 15 \\
\hline
\end{tabular}

\section{Bus utilization}

त Number of Trips - old system $\quad \square$ Number of Trips - new system

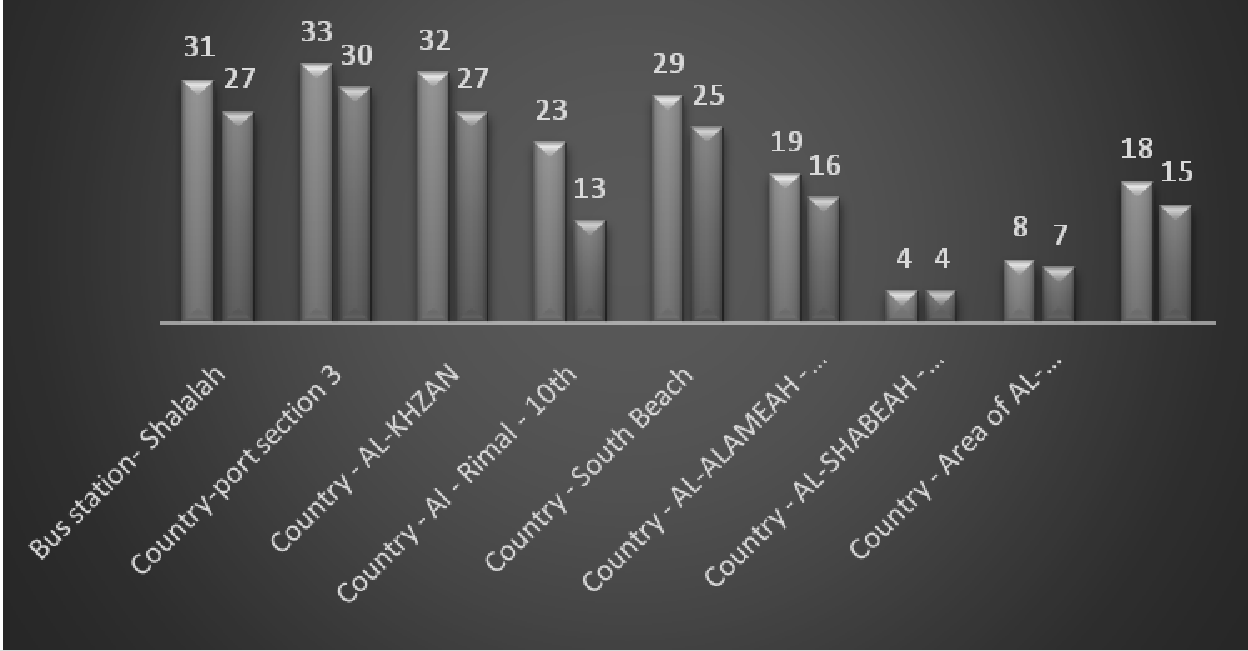

B- Distance and Trip Coverage

Total Kilometers covered by buses for route $i$ is the sum of Kilometer covered during all the four shifts, total distance coverage of the current and the improved systems. The distance covered on each shift was computed by multiplying the number of buses assigned to a given route at that shift by the number of trips that can be made by a single bus and by the route length. The total distance covered by the improved system is $479623 \mathrm{Km}$ per day; while for the existing system is about $248482 \mathrm{Km}$ per day. This shows an increase of $32 \%$ in the daily distance coverage to serve the same number of passengers wide covered. 
Total distance coverage of the current (multiplying the number of buses assigned to a given route at that shift by the number of trips that can be made by a single bus and by the route length) $=61655.6 \mathrm{KM}$.

\begin{tabular}{|c|c|c|c|c|c|}
\hline$\#$ & ROUT NAMR & $\begin{array}{c}\text { the number of } \\
\text { buses }\end{array}$ & $\begin{array}{c}\text { number of } \\
\text { trips }\end{array}$ & $\begin{array}{l}\text { route } \\
\text { length }\end{array}$ & $\begin{array}{c}\text { distance } \\
\text { coverage }\end{array}$ \\
\hline 1 & Bus station- Shalalah & 1 & 31 & 5 & 155 \\
\hline 2 & Country-port section 3 & 1 & 33 & 43 & 1419 \\
\hline 3 & Country - AL-KHZAN & 1 & 32 & 5 & 160 \\
\hline 4 & Country - Al - Rimal - 10th & 3 & 23 & 10 & 690 \\
\hline 5 & Country - South Beach & 46 & 29 & 43 & 57362 \\
\hline 6 & $\begin{array}{l}\text { Country - AL-ALAMEAH - AL- } \\
\text { MHDOUD }\end{array}$ & 6 & 19 & 10 & 1140 \\
\hline 7 & $\begin{array}{l}\text { Country - AL-SHABEAH - AL- } \\
\text { MHDOUD }\end{array}$ & 2 & 4 & 9.5 & 76 \\
\hline 8 & Country - Area of AL-MHDOUD & 5 & 8 & 8.6 & 344 \\
\hline \multirow[t]{2}{*}{9} & Country -AL-MHDOUD Western & 2 & 18 & 8.6 & 309.6 \\
\hline & & & & & 61655.6 K.M \\
\hline
\end{tabular}

The improved systems (multiplying the number of buses assigned to a given route at that shift by the number of trips that can be made by a single bus and by the route length)

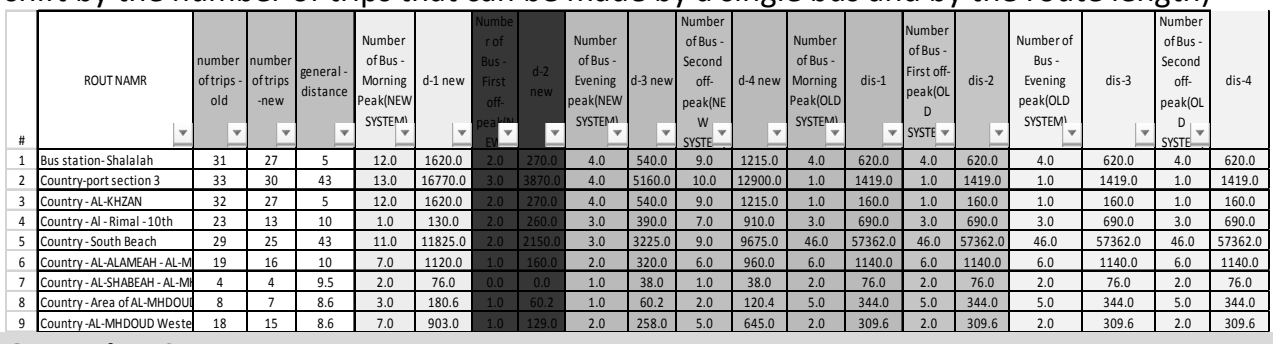

C- Operating Costs

The improvements made were also validated using the various operating costs of the enterprise. Total daily operating cost for each route is the sum of operating costs for all the shifts. From the comparison made, the findings show that the average daily operating cost for the existing system is

- Labor wages $=20 \mathrm{~J} . \mathrm{D}$ per day--- $\rightarrow 600 \mathrm{~J} . \mathrm{D}$ per month (in new system remaining same).

- Gas oil $=1.83 \mathrm{~J} . \mathrm{D}$ per day-- $\rightarrow 55 \mathrm{~J} . \mathrm{D}$ per month.(in new system half value)

- $\quad$ Re-license \& insurance= 3 J.D per day $--\rightarrow 90$ per month (in new system remaining same).

- Tires $=2.33 \mathrm{~J} . \mathrm{D}$ per day $----\rightarrow 160 * 6=960 \mathrm{~J}$. D per YEAR (in new system half value)

- Solar $=40 \mathrm{~J} . \mathrm{D}$ per day $---\rightarrow 1200 \mathrm{~J}$. D per month every (20) litter solar $=80 \mathrm{~K} . \mathrm{M}$ (in new system half value)

- Depreciation8.33 J. D per day $---\rightarrow 2988 \mathrm{~J}$. D per month (Vehicle price / production age $=$ $45000 /(15 * 12 * 30)$ - straight-line method (in new system remaining same). 
Modeling and Analysis of Bus Scheduling Systems...

\begin{tabular}{|l|c|c|}
\hline \multicolumn{1}{|c|}{ ITEMS } & Current operating cost / J. D & new operating cost / J. D \\
\hline Labor wages & 20 & 20 \\
\hline Gas oil & 1.83 & 0.9 \\
\hline Re-license \& insurance & 3 & 3 \\
\hline Tires & 2.33 & 1.3 \\
\hline Solar & 40 & 20 \\
\hline Depreciation & 8.33 & 8.33 \\
\hline \multicolumn{2}{|c|}{} \\
\hline Total cost & 75.49 & 53.53 \\
\hline Total revenue & 100 & 100 \\
\hline Profit & $\mathbf{2 4 . 5 1}$ & $\mathbf{4 6 . 4 7}$ \\
\hline
\end{tabular}

\section{Operating cost}

- Current operating cost / J. D new operating cost / J. D

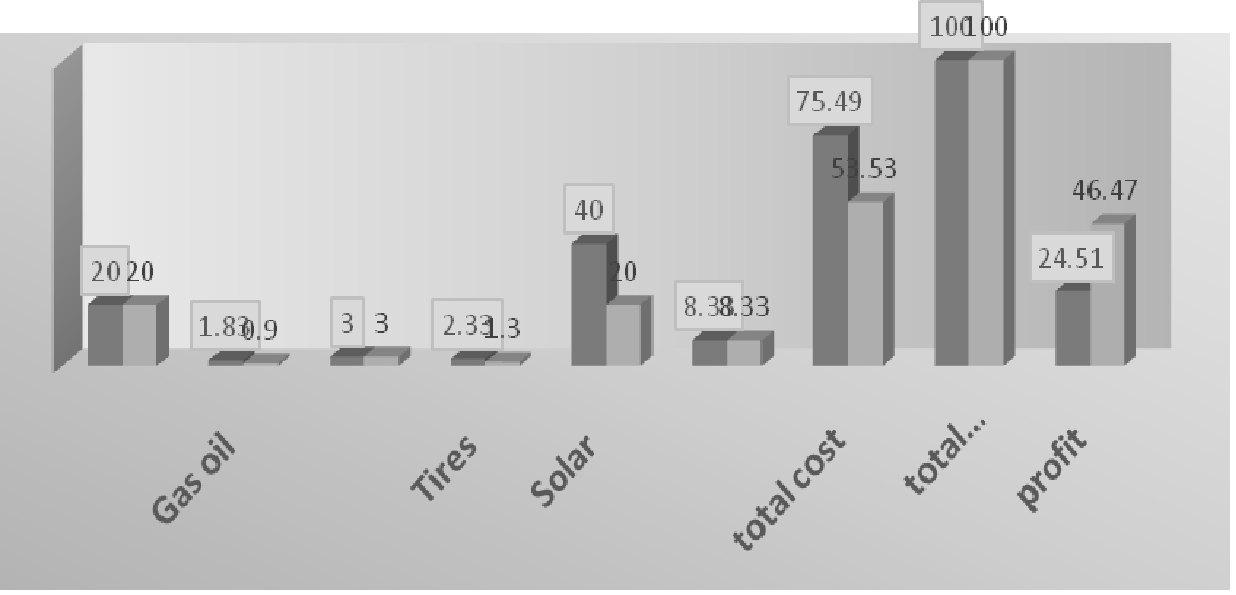

The 22-seat capacity bus with total capacity of 44 passengers is labeled as bus type- 1 and the 50-seat capacity with total capacity of 100 passengers as bus type-II. Each of them has a fleet size of 78 and 11 respectively. The total bus capacity is computed as the sum of the seat and standing capacity. For this paper, it is determined based on international standards. Thus, the objective function of the LP model is to determine the optimum number and mix of these two types of buses.

\section{Conclusions \& Discussion}

The main purpose of this study is to develop an optimal bus assignment method using Linear Programming (LP). The LP-model deals with the assignment of optimum number of buses for each shift with the available fleet size and different constraints in such a way that bus utilization is improved, and operating costs are reduced with better service level. The model determines the total number of buses required with the objective of optimizing the number of buses required so that the operation cost would be minimized indirectly. Therefore, based on the study statistical results, the findings of the study show that the existing scheduling systems of AQABA buses has shown low performances on 
the bus utilization, operating costs, daily trips and distance covered. This is mainly since fixed numbers of buses are assigned to routes without considering the variability of demand. However, the operational performances of the LP-model have shown better performance improvement over the existing bus scheduling system, almost, in all the above parameters. The existing bus scheduling system has lower average utilization of buses compared with the improved one. The bus utilization per route per shift also shows significant improvement over the existing system when the comparison was made based on shift.

The study found that there is a positive effect bus utilization on reduce cost in public transportation, the findings show that the improved system has better bus utilization (164) trip than the existing one (197) trip / per day. The existing system has a maximum of about $83.2 \%$ daily bus utilization, this indicates that the correct adoption and developing of L.P concluded to accomplish the company goals in increase operational and financial outcomes - (reduce cost) Additionally, the successful application of L.P will improve and enhance the quality of company services.

Also, the study found that there is a positive effect total number of trips made Which is reflected positively on various operating costs on reduce cost in public transportation on reduce cost in public transportation. About cost, the findings show that the improved system has well reduce cost in public transportation (53.53) J.D than the existing one (75.49) \$J.D that mean reduce cost by \%71 and increase profit from 24.51-J.D to 46.47J.D / per day, that mean the improved system results in a saving of 21.96 J.D per day . Moreover, the study found that there is a positive effect of total distance travelled on reduce cost in public transportation, the findings show that the total distance covered by the improved system is $79,623 \mathrm{Km}$ per day; while for the existing system is about $248482.7 \mathrm{Km}$ per day. This shows a reduction of $32 \%$ in the daily distance coverage to serve the same number of passengers, the distance covered on each shift was computed by multiplying the number of buses assigned to a given route at that shift by the number of trips that can be made by a single bus and by the route length, In addition to the saving in all the parameters, the improved system also reduces the waiting time, improves the service quality and reduces passenger congestion by scheduling buses based on the international standard bus capacity. It also secures a minimum of one round trip in every 30 minutes for each route to improve the service quality. The new system has also a significant reduction on the total Kilometers covered while improving the total trips made on daily basis.

\section{Recommendations}

Based on the study results, the researchers suggest the following recommendation that might be helpful to develop an optimum bus assignment method using Linear Programming (LP), Where the LP-model deals with the assignment of optimum number of buses for each shift with the available fleet size of the company and different constraints in such a way that bus utilization is improved, and operating costs are reduced with better service level, The model determines the total number of buses required with the objective of optimizing the number of buses required so that the operation cost would be minimized indirectly.

- There are no bus stops: AQABA is growing fast leading to an increased demand for public transport services and facilities. This has subsequently led to the capacity of bus stops 
with single and double loading areas are important for the accessibility and reliability of public transport. Lack of capacity of the loading area increases travel time for busses There are no specific timetables for bus schedules for public transport

- There are no maps shown on the plates that determine the path of each bus on the roads.

Taking into consideration all the above points and working on their application to achieve high quality of transport and high satisfaction for users of public transport network.

References

1. http://dosweb.dos.gov.jo/ar/. - department of statistic

2. B. Stefan. "An overview of scheduling models in De-cision Support \& Operations Research Lab", University of Paderborn, Warburger, Germany, 2002.

3. S. Das, A. Mukhopadhyay, A. Roy, A. Abraham and Bijaya Panigrahi, Exploratory Power of the Harmony Search Algorithm: Analysis and Improvements for Global Numerical Optimization, IEEE Transactions.

4. H. Liu, A. Abraham and M. Clerc, Chaotic Dynamic Characteristics in Swarm Intelligence, Applied Soft Computing Journal, Elsevier Science, 7(3), pp. 1019-1026, 2007.

5. A. Abraham, Intelligent Systems: Architectures and Perspectives, Recent Advances in Intelligent Paradigms and Applications, Abraham A., Jain L. and Kacprzyk J. (Eds.), Studies in Fuzziness and Soft Computing, Springer Verlag Germany, ISBN 3790815381, Chapter 1, pp. 1-35, 2002.

6. S. Das, A. Biswas, S. Dasgupta and A. Abraham, Bacterial Foraging Optimization Algorithm: Theoretical Foundations, Analysis, and Applications, Foundations of Computational Intelligence Volume 3: Global Optimization, Studies in Computational Intelligence, Springer Verlag, Germany, ISBN: 978-3-642-01084-2, pp. 23-55, 2009.

7. F. Xhafa and A. Abraham, Meta-heuristics for Grid Scheduling Problems, Metaheuristics for Scheduling: Distributed Computing Environments, Studies in Computational Intelligence, Springer Verlag, Germany, ISBN: 978-3-540-69260-7, pp. 1-37, 2008.

8. A. Wren and D. Wren. "A genetic algorithm for public transport driver scheduling", Computers and Operations Research, 1995.

9. F. Daganzo. "A dynamic approach to eliminate bus bunching", Transportation research Part B, 2009.

10. F. Salzborn. “Optimal Bus Scheduling”, Transportation Science, 6(2), pp. 137-148, 1972.

11. G. Clarke and J. Wright." Scheduling of vehicles from a central depot to a number of delivery points", Operations Research 12, pp. 568-581, 1964.

12. G. Dantzig and J.H. Ramser. "The truck dispatching problem", Journal of Management Science, Management Science 6(1), pp. 80-91, 1959. 
13. G. Clarke and J. Wright." Scheduling of vehicles from a central depot to a number of delivery points", Operations Research, 12, pp. 568-581, 1964.

14. G. Laporte, F. Louveaux, H. and Mercure. "Models and exact solutions for a class of stochastic location-routing problems", European Journal of Operational Research.

15. H. Calvete, G. Carmen, O. Mara, Jos, and V. Beln,Snchez, "Vehicle routing problems with soft time windows: an optimization based approach", Journal of Monografas del Seminario Matemtico Garca de Galdeano, 31, pp. 295-304, 2004.

16. J. Beasley, and B. Cao. "A tree search algorithm for the crew scheduling problem", European Journal of Operational Researchl, 1996.

17. Snchez, "Vehicle routing problems with soft time windows: an optimization-based approach", Journal of Monografas del Seminario Matemtico Garca de Galdeano, 31, pp. 295-304, 2004.

18. J. Christopher, Goodson. "Solutions Methodologies for VRP with Stochastic Demand", Dissertation, University of lowa, 2010.

19. M. Fischetti, A. Lodi, S. Martello and P. Toth " A polyhedral approach to simplified crew and vehicle scheduling problems", Management Science, 27(6), pp. 1-18, 2001.

20. R. Freling, C. Boender, and J. Pinto. An IntegratedApproach to Vehicle and Crew Scheduling. ErasmusUniversity Rotterdam, Econometric Institute, 1995.

21. Y. Shangyao, T. Ching-Hui and F. Tseng-Chih. "An airline scheduling model and solution algorithms under stochastic demands", European Journal of Operation Research, 190, pp. 22-39, 2008.

22. A. Wren and D. Wren. "A genetic algorithm for public transport driver scheduling", Computers and Operations Research, 1995.

23. B. Stefan. "An overview of scheduling models in De-cision Support \& Operations Research Lab",University of Paderborn, Warburger, Germany, 2002.

24. J. Beasley, and B. Cao. "A tree search algorithm for the crew scheduling problem", European Journal of Operational Researchl, 1996.

25. M. Fischetti, A. Lodi, S. Martello and P. Toth " A polyhedral approach to simplified crew and vehicle scheduling problems", Management Science, 27(6), pp. 1-18, 2001.

26. R. Freling, C. Boender, and J. Pinto. An Integrated Approach to Vehicle and Crew Scheduling. Erasmus University Rotterdam, Econometric Institute, 1995. 
27. S. Mehmet, A. Mawada and A. Jafar. "Scheduling and Routing of City Buses at Kuwait Public Transport", International Journal of Applied Operational Research, 1(3), pp. 11-32, 2012.

28. B. Shlifer and G. Gavish. "An approach for solving a class of transportation scheduling problems", European Journal of Operational Research, 3, pp. 122-134, 1978.

29. F. Daganzo. "A dynamic approach to eliminate bus bunching", Transportation research Part B, 2009.

30. L. Fu and X. Yang. "Design and Implementation of Bus-Holding Control Strategies with Real-Time Information", Transportation Research Record: Journal of the Transportaion Research Board, (1791), pp. 6-12, TRB, National Rreseafch Council, Washington, D.C., 2002.

31. M. Dessouky, A. Nowroozi, and K. Mourikas. "Bus dispatching at timed transfer transit stations using bus tracking technology" University of Southern California, Department of Industrial and Systems Engineering, 1999.

32. N. Kliewer. "A time space network based exact optimization model for multi-depot bus scheduling", 175(3), pp.80-87, 2006.

33. N. Van Oort, M. Boterman and D. Van Nes. "Effect of driving-time determination and holding points on reliability", Conference on Advanced Systems for Public Transport. Hong Kong, 2009.

34. S. Mehmet, A. Mawada and A. Jafar. "Scheduling and Routing of City Buses at Kuwait Public Transport", International Journal of Applied Operational Research, 1(3), pp. 11-32, 2012.

35. www.aseza.jo. 